$\xi^{2}=-1$

\title{
Evaluation of Ground Water Potential in Ekpri-Ikang, Bakassi Local Government Area, Cross River State, Nigeria. "A Case Study of Open Bible Standard Church Premises."
}

\author{
Emmanuel Bassey Umoren, Okechukwu Ebuka Agbasi *, Eniang Obongekeme Emmanuel \\ Department of Physics, University of Uyo, Uyo Akwa Ibom State \\ *Corresponding authorE-mail: ebukasean09@yahoo.com
}

\begin{abstract}
Electrical resistivity survey using Schlumberger Vertical Electrical Sounding (VES) field technique was carried out at Ekpri Ikang in Bakassi local government area of Cross River State. The survey is aimed at determining the water bearing formation of the area. Data acquired were interpreted using WinRes Program into a curve showing true resistivity and thickness of the subsurface layers. Result indicates that there are four distinct layers in the study area. Analyses of the data and interpretation of the sounding curve reveals that the water bearing layer exist in the layer two (2) and three (3) with resistivity values of $347.6 \Omega$ and $375.5 \Omega$, also with thickness of $14.5 \mathrm{~m}$ and $21.3 \mathrm{~m}$, depth of $39.6 \mathrm{~m}$ and $61.0 \mathrm{~m}$. It is therefore recommended that boreholes for good drinking water be drilled to the layer two (2) and three (3) of the investigated area.
\end{abstract}

Keywords: Aquiferous Unit; Borehole; Groundwater; Resistivity; Vertical Electrical Sounding (VES).

\section{Introduction}

Groundwater is described as water which exists below the earth surface within saturated layers of sand, gravel and pore spaces in sedimentary as well as crystalline rocks (Oseji and Ofomola, 2010). According to Todd (2004) "groundwater is the water occupying all the empty spaces within a geologic stratum". It is among the natural resources of prime importance to man throughout the world. Oseji and Adegoke-Anthony (2005) noted that groundwater occurs in many types of geologic formations. Those known as aquifer are the most important permeable material to yield significant quantities of water to wells and spring (Abiola et al., 2009). The vertical electrical sounding method was chosen for this study because the instrumentation is simple and easily available; also interpretation and analysis of data is economical and less tedious. Groundwater, through the various dissolved salts it contains, is ionically conductive and enables electric currents to flow into the ground (Bernard, 2003). Tyson (1993) also noted that all groundwater contain natural occurring minerals such as iron and manganese in varied concentration. Consequently, measuring the ground resistivity gives the possibility to identify the presence of water, taking into consideration the following properties:

- A hard rock without pores or fracture and dry sand without water are very resistive: several thousand ohm.m.

- A porous or fractured rock bearing free water has a resistivity that depends on the resistivity of the water and on the porosity of the rock; several hundred to several thousand ohm.m.

- An impermeable clay layer, which has bound water, has a low resistivity: several units to several tens ohm.m.
- Mineral ore bodies (iron, sulphides) have very low resistivity due to their electronic conduction: usually lower or much lower than 1 ohm.m.

Olorunfemi and Oluruniwo (1987) used the electrical resistivity method for groundwater investigation of geo- electrical and hydrogeologic characteristics of areas in South West Nigeria. They investigated groundwater prospect in the basement complex of rocks of Southern Western Nigeria. They concluded that local geological condition play an important role in the yield of boreholes located in the basement complex area in South Western Nigeria.

Gnanasunder and Elango (1999) carried out groundwater quality assessment of a coastal aquifer lying South of Chennai City, Madias India using electric techniques. This study was able to delineate a fresh water ridge of good groundwater quality in the central portion of the coastal aquifer while the Eastern and Western margins of the aquifer however contained groundwater of poor quality.

Ajayi and Adegoke-Anthony (1987) investigated groundwater prospect in the basement of complex rocks of southwestern Nigeria. They concluded that local geological condition play an important role in the yield of boreholes located in the basement complex area of southwestern Nigeria.

Olorunfemi and Fasuyi (1993) used the electrical resistivity method in investigation of geo-electric and hydro-geologic characteristic of areas in southern west Nigeria.

Agbasi and Etuk (2016) carried out geoelectric survey employing Vertical Electrical sounding (VES) in parts of Ikot Abasi Local Government Area, Akwa Ibom state, Nigeria to be a guide for the suitable position of borehole in order to avoid wild cat drilling and also to avoid salt intrusions using the VES geophysical techniques and also shows that most parts of the study area have aquifer with poor protecting capacity $(<0.1$ mhos) resulting in high salt intrusion. 
Ako and Osundu (1986) carried out groundwater investigation at Darazo on the kerri-kerri formation; they concluded that DarZarouk parameters are related to borehole characteristics. The conclusion holds that the highest traverse resistance (T) corresponds to the zone with the highest borehole yield.

\section{Location and geology of survey area}

The survey area Ekpri-Ikang in Bakassi L.G.A. lies in the southern senatorial district of Cross River State and it is about 45 minutes' drive from Calabar, the capital city of the state. It is located within latitude $04^{\circ} 49^{\prime} 35.8^{\prime \prime} \mathrm{N}$ and longitude $008^{\circ} 30^{\prime} 23.1^{\prime \prime} \mathrm{E}$ at about $36 \mathrm{~m}$ above sea level.

Geologically, the soil is composed of materials similar to those of the Mkporo shale which is dark and carbonaceous. The marl is yellowish and in bands up to $30 \mathrm{~m}$ thick. It is bioturbated and highly fossil ferrous.

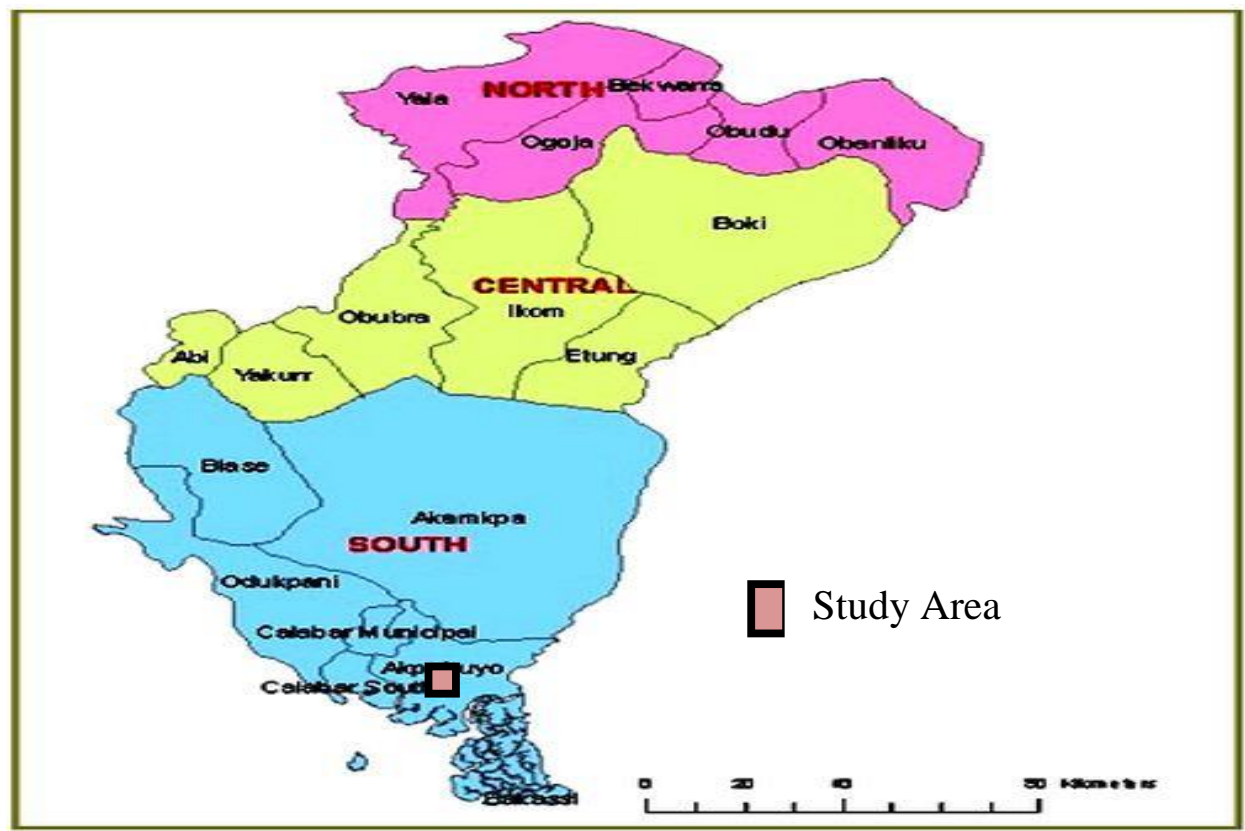

Fig. 1: Map of Cross River State Showing the Study Area (Www.Crossriverwatch.Com, 2013).

\section{Methodology}

Electrical geophysical prospecting methods detect the surface effects produced by electric current flow in the ground. Using electrical methods, one may measure potentials, currents and electromagnetic fields which occur naturally or are introduced artificially in the ground. In addition, the measurements can be made in a variety of ways to determine a variety of results. There is a much greater variety of electrical and electromagnetic techniques available than in the other prospecting methods, where only a single field or force or anomalous property is used.

Basically, it is the enormous variation in electrical resistivity found in different rocks and minerals which makes these techniques possible (Telford et al, 1976). Furthermore, this method is employed in characterizing vertical and. lateral discontinuities. In subsurface electrical properties, vertical changes are measured using the vertical electrical sounding (VES) techniques while lateral changes are measured using the horizontal resistivity profiling (HRP) technique (Oseji et al., 2005).

Of all surface geophysical methods, the electrical resistivity method has been applied most widely for ground water investigations out of the entire surface geophysical methods. Examples are the use of electrical resistivity profiling and vertical electrical sound- ing methods in delineation of various aquiferous units of southwestern Nigeria crystalline basement complex by Olorunfemi and Olorunniwo (1985), Olorunfemi and Opadokun (1986). The electrical resistivity method can be best employed to estimate the thickness of overburden and the thickness of weathered/fractured zones with reasonable accuracy. Though both Wenner and Schlumberger electrode configuration methods are popularly employed, the Schlumberger electrode configuration method is more suited to the study area, ensuring better results. The method has practical, operational and interpretational advantages over other methods such as the Wenner method of electrode arrangement (Zohdy et al., 1974).

Most of the electrical resistivity techniques require injection of electrical currents into the subsurface via a pair of electrodes planted on the ground. By measuring the resulting variations in electrical potential at other pairs of planted electrodes, it is possible to determine the variations in resistivity (Dobrin, 1988; Ozcep et al., 2009; Alile et al., 2011). A conventional vertical electrical sounding (VES) survey was used for quantitative interpretation where the center point of the array remains fixed and the electrode spacing is increased for deeper penetration (Loke,1999). 


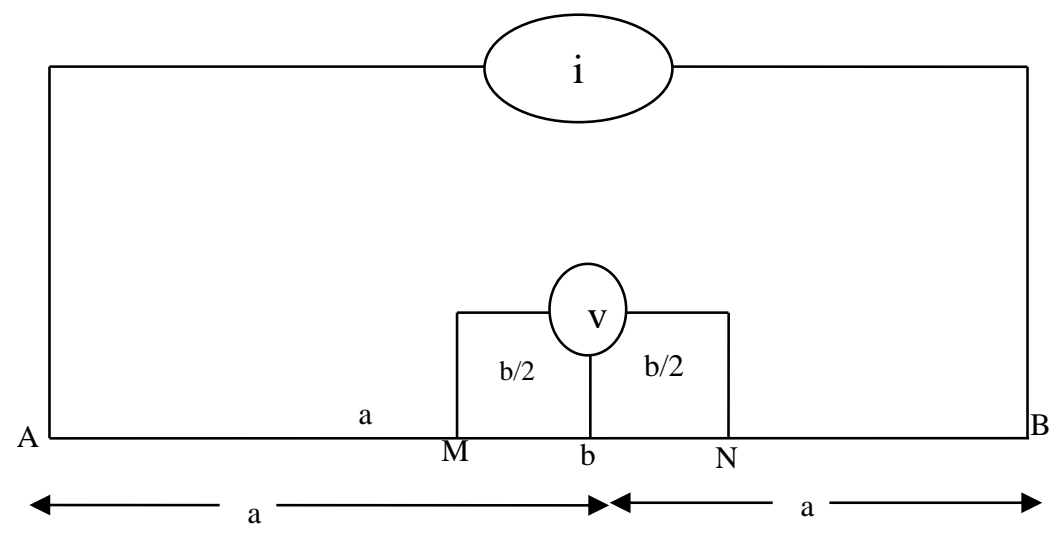

Fig. 2: Schlumberger Array Configuration (Loke 1999).

In carrying out resistivity sounding survey, electrodes are distributed along a line centered about a midpoint that is considered the location of the sounding. The electrode arrangement used in data acquisition is the Schlumberger array of electrodes. The Schlumberger survey involves the use of two current electrodes labeled A and $\mathrm{B}$, and two potential electrodes $\mathrm{M}$ and $\mathrm{N}$ placed in line with one another and centered on some location. It is worthy to state that the potential and current electrodes are not placed equidistant from one another. To acquire the resistivity data in the field, current is introduced into the ground through the current electrodes and the potential electrodes are then used to quantitatively measure the voltage pattern (Alabi et al., 2010). The geometric arrangement for this array is shown in Figure 2.

Instruments used during the survey include ABEM terrameter (SAS 300), measuring tapes, current cables, potential cables, electrodes, hammers, GPs, crocodile chips, 12 -volt battery.

With the help of a measuring tape, the initial potential electrode spacing was at $0.25 \mathrm{~m}$ and the current electrode spacing was at $1 \mathrm{~m}$ from both ends. After marking out these points, the first reading was taken after which the spacing of the potential electrodes and current electrodes were moved as designated using the Schlumberger Array. Reading was taken by switching on terrameter after which the measure key was pressed so as to have the value dis- played on the screen. The maximum current electrode spread was $300 \mathrm{~m}$.

Before the resistivity data was obtained, current was introduced into the ground through the current electrode and their respective potential differences were measured between the protected electrodes after which the sub-surface apparent resistivity was calculated. Electrical resistivity surveys have been employed for many years in geophysical investigation aimed at ground water research. These surveys have successfully delineated aquifers in situations where significant resistivity differences exist between them and their surroundings formations.

The resistivity data obtained using these different electrode spacing at fixed location were then evaluated to yield a sounding curve for each occupied site and corresponding geological model which represents the variation of layer resistivity with depth. A total of 4 soundings were carried out with a maximum spread of $300 \mathrm{~m}$ covering about 2 stations per station.

The Schlumberger array was adopted with a maximum half current electrode spacing $\left(\frac{\mathrm{AB}}{2}\right)$ of $300 \mathrm{~m}$.

$\therefore$ Therefore a total of 8 stations covering distance of $300 \mathrm{~m}$ horizontal resistivity profiling were covered.

Table 1: Ves Data Acquired at Open Bible Standard Church, Ekpri Ikang. Schlumberger Array. Northing: $44935^{\circ} \cdot 8$, Easting: $83023^{\circ} 1$ Elevation: 36m

\begin{tabular}{|c|c|c|c|c|c|}
\hline S/N & $\mathrm{AB} / 2(\mathrm{~m})$ & $\mathrm{MN} / 2(\mathrm{~m})$ & Geometrical Factor (K) & $\mathrm{R}$ & $\rho(\Omega-m)$ \\
\hline 1 & 1 & 0.25 & 5.89 & 439.511 & 2588.71 \\
\hline 2 & 1.5 & 0.25 & 13.75 & 202.073 & 2778.50 \\
\hline 3 & 2 & 0.25 & 24.74 & 117.722 & 2912.44 \\
\hline 4 & 3 & 0.25 & 56.16 & 55.2367 & 3101.7 \\
\hline 5 & 3 & 0.5 & 27.49 & ------ & ------ \\
\hline 6 & 4 & 0.5 & 49.49 & 61.4240 & 3039.87 \\
\hline 7 & 4 & 0.25 & 100.15 & 30.8119 & 3085.6 \\
\hline 8 & 5 & 0.5 & 77.76 & 37.7859 & 2937.7 \\
\hline 9 & 6 & 0.5 & 112.33 & 25.2342 & 2829.92 \\
\hline 10 & 8 & 0.5 & 200.30 & 14.3670 & 2876.3 \\
\hline 11 & 8 & 1 & 98.97 & ------ & ------ \\
\hline 12 & 10 & 1 & 155.53 & 18.2201 & 2830.1 \\
\hline 13 & 10 & 0.5 & 313.41 & 9.03231 & 2820.6 \\
\hline 14 & 15 & 1 & 351.90 & 7.38654 & 2568.8 \\
\hline 15 & 20 & 1 & 626.83 & 4.61406 & 2883.2 \\
\hline 16 & 30 & 1 & 1412.33 & 1.83654 & 2542 \\
\hline 17 & 30 & 2.5 & 561.63 & ------ & ------ \\
\hline 18 & 40 & 2.5 & 1001.51 & 1.98117 & 1981.9 \\
\hline 19 & 40 & 1 & 2512.03 & 0.82456 & 2059 \\
\hline 20 & 50 & 2.5 & 1567.07 & 1.00907 & 1567 \\
\hline 21 & 60 & 2.5 & 2258.31 & 0.54573 & 1219.3 \\
\hline 22 & 80 & 2.5 & 4017.83 & 0.22253 & 883.9 \\
\hline 23 & 80 & 10 & 989.73 & ------ & ------ \\
\hline 24 & 100 & 10 & 1555.29 & 0.45767 & 699.75 \\
\hline 25 & 100 & 2.5 & 6280.07 & 0.11202 & 690.80 \\
\hline 26 & 150 & 10 & 3519.04 & 0.18326 & 633.42 \\
\hline 27 & 125 & 10 & 2438.98 & ------ & ------ \\
\hline 28 & 200 & 10 & 6268.29 & 0.12494 & 752.16 \\
\hline 29 & 250 & 10 & 9803.04 & 0.7785 & 754 \\
\hline 30 & 300 & 10 & 14123.29 & 0.04874 & 564.9 \\
\hline
\end{tabular}


Table 2: VES Data Acquired at Open Bible Standard Church, EKPRI IKANG. Schlumberger Array. Northing: $44935^{\circ} 8$, Easting: $83023^{\circ} 1$ Elevation:

\begin{tabular}{|c|c|c|c|c|c|}
\hline $\mathrm{S} / \mathrm{N}$ & $\mathrm{AB} / 2(\mathrm{~m})$ & $\mathrm{MN} / 2(\mathrm{~m})$ & Geometrical Factor $(\mathrm{K})$ & $\mathrm{R}$ & $\rho(\Omega-m)$ \\
\hline 1 & 1 & 0.25 & 5.89 & 439.511 & 2588.71 \\
\hline 2 & 1.5 & 0.25 & 13.75 & 202.073 & 2778.50 \\
\hline 3 & 2 & 0.25 & 24.74 & 117.722 & 2912.44 \\
\hline 4 & 3 & 0.25 & 56.16 & 55.2367 & 3101.7 \\
\hline 5 & 3 & 0.5 & 27.49 & ------ & ------ \\
\hline 6 & 4 & 0.5 & 49.49 & 61.4240 & 3039.87 \\
\hline 7 & 4 & 0.25 & 100.15 & 30.8119 & 3085.6 \\
\hline 9 & 6 & 0.5 & 112.33 & 25.2342 & 2829.92 \\
\hline 10 & 8 & 0.5 & 200.30 & 14.3670 & 2876.3 \\
\hline 11 & 8 & 1 & 98.97 & ------ & ------ \\
\hline 12 & 10 & 1 & 155.53 & 18.2201 & 2830.1 \\
\hline 13 & 10 & 0.5 & 313.41 & 9.03231 & 2820.6 \\
\hline 14 & 15 & 1 & 351.90 & 7.38654 & 2568.8 \\
\hline 15 & 20 & 1 & 626.83 & 4.61406 & 2883.2 \\
\hline 16 & 30 & 1 & 1412.33 & 1.83654 & 2542 \\
\hline 18 & 40 & 2.5 & 1001.51 & 1.98117 & 1981.9 \\
\hline 19 & 40 & 1 & 2512.03 & 0.82456 & 2059 \\
\hline 20 & 50 & 2.5 & 1567.07 & 1.00907 & 1567 \\
\hline 21 & 60 & 2.5 & 2258.31 & 0.54573 & 1219.3 \\
\hline 22 & 80 & 2.5 & 4017.83 & 0.22253 & 883.9 \\
\hline 23 & 80 & 10 & 989.73 & ------ & ------ \\
\hline 24 & 100 & 10 & 1555.29 & 0.45767 & 699.75 \\
\hline 25 & 100 & 2.5 & 6280.07 & 0.11202 & 690.80 \\
\hline 26 & 150 & 10 & 3519.04 & 0.18326 & 633.42 \\
\hline 27 & 125 & 10 & 2438.98 & ------ & ------ \\
\hline 28 & 200 & 10 & 6268.29 & 0.12494 & 752.16 \\
\hline 29 & 250 & 10 & 9803.04 & 0.7785 & 754 \\
\hline 30 & 300 & 10 & 14123.29 & 0.04874 & 564.9 \\
\hline
\end{tabular}

\section{Results and discussion}

Measured resistivity values of the study area are presented by the VES data in Table 2. Computer iteration using WinRes Program yielded the sounding curve shown in Figure 3.
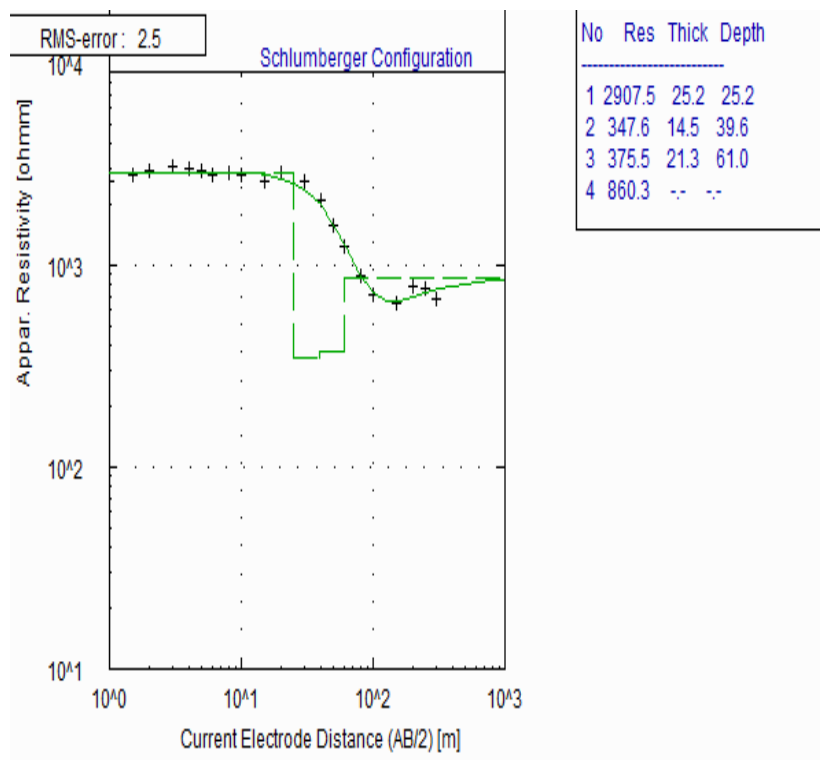

Fig. 3: Four Layer VES Curve.

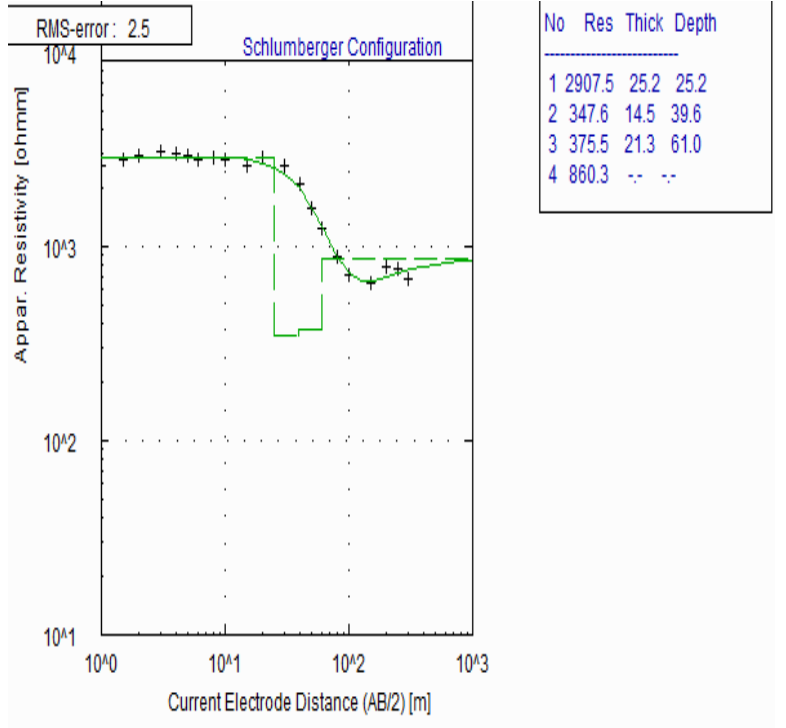

Fig. 4: Four Layer VES Curve.

Based on the VES curve for the four layers investigated in Figure 4 and their corresponding resistivity values;

Layer 1 which has the highest resistivity value of $2907.5 \Omega \mathrm{m}$ is interpreted to be a dry sandy formation. This is true for a tight formation.

Layer 2 and 3 with low resistivity values of $347.6 \Omega \mathrm{m}$ and $375.5 \Omega \mathrm{m}$ respectively are interpreted to be the water being formation (acquifer). This is true as resistivity values decreases in Figure 4 indicating a wet porous and permeable formation.

In layer 4 , the resistivity values increases again, indicating that it is a tight and dry sandy formation which contains no water. In conclusion, layer 2 and 3 are the aquiferous unit.

The application of vertical electrical sounding (VES) technique has provided detailed information on the thickness and hydroelectrical characteristics of the aquifer in the study area.

The result of the interpreted data reveals Layer 2 and 3 as the promising layer for any drilling operations. Drilling at this point is 
expected to reach at least a depth of $60 \mathrm{~m}$ to enable the entire thickness of the aquiferous layer to be penetrated.

\section{References}

[1] Abiola, O., Enikanselu, P. A. and Oladapo, M. I. (2009). Groundwater potential and aquifer protective capacity of overburden units in Ado-Ekiti Southwestern Nigeria, International Journal of Physics H. (3): 120-132.

[2] Ajayi, O. and Adegoke-Anthony, C. W. (1987). Groundwater prospects in the basement complex rocks of southwestern Nigeria. Journal of African Earth Sciences, 7(1): 227-235. https://doi.org/10.1016/0899-5362(88)90070-X

[3] Ajayi, D. and Adegoke-Anthony, C. W. (1988). Causes of borehole failure in crystalline rocks of south western Nigeria. Procedure of first Biennial natural Hydrology Symposium, 466-489.

[4] Ako, B. D. and Osondu, V. C. (1986). Electrical Resistivity of the Kerri-Kerri formation, Darazo, Nigeria: Journal of African Earth Sciences, 5(5): 527-534. $\quad$ https://doi.org/10.1016/08995362(86)90062-X.

[5] Alabi, A. A., Bello, R., Ogunghe, A. S. and Oyerinde, H. O. (2010) Determination of groundwater potential in Lagos State University, Ojo; using geo-electric methods (Vertical electrical sounding and horizontal profiling), Rep. Opin 2(5): 68-75.

[6] Alile, O. M., Ujuanbi, O. and Erbuomwan, I. A. (2011). Geoelectric investigation of groundwater in Obaretin-Iyan Onnon locality, Edo state, Nigeria. J. G.

[7] Bernard, J. (2003). Short notes on the depth of investigating of electrical methods, Page 2-4, Web accessed 4 April 2012. http://www.heritagegeophysics.com/papers/depthofinvestigation.pd f. Dobrin, (1988). Introduction to geophysical prospecting fourth edition.

[8] Loke, M. H. (1999). Electrical imaging survey for environmenta and engineering studies. A practical guide to 2D and 3D surveys: Austin, Texas, Advanced Geosciences Inc., Page 57.

[9] Okechukwu E Agbasi and Sunday E Edet (2016) HydroGeoelectric Study of Aquifer Potential in Parts of Ikot Abasi Local Government area, Akwa Ibom State, Using Electrical Resistivity Soundings. International Journal of Geology and Earth Sciences. 2(4): $43-54,2016$.

[10] Olorunfemi, M. O. and Oloruniwo (1985). Geo-electric parameters and aquifer characteristics of some part of southern Nigeria: Geological application Hydrogeologia, (20): Page 99-109.

[11] Olurunfemi, M. O. and Fasuyi, S. A. (1993). Aquifer types and the geo-electric hydro-geologic characteristics parts of the centra basement terrain of Nigeria, Niger State: Journal of African Earth Sciences, 16(3): 309-317. https://doi.org/10.1016/08995362(93)90051-Q

[12] Olorunfemi, M. O. and Opadokun, M. A. (1986). On the application of surface geophysical measurement in geological mapping complex of southwest Nigeia as a case study. Journal of African Earth Sciences, Vol. 613, Page 287-291.

[13] Oseji, J. O. and Ofomola, M. O. (2010). Determination of Groundwater flow direction in Utagba-Ogbe kingdom. Ndukwa land area of Delta state Nigeria. Journal of Earth Science, 4(1): 32-34

[14] Oseji, J. O., Atakpo, E. A. and Okolie, E. C. (2005). Geo-electric investigation of the aquifer characteristics and groundwater in Kwale, Delta State Nigeria, Journal of Applied Science and Environmental Management, (9): 157-160.

[15] Ozcep, F., Tezel, O., Asci, M. (2009). Correlation between electrical resistivity and soil-water content; Istanbul and Glocuk, Internal Journal of Physical Sciences, 4(6): 362-365.

[16] Telford, W. M., Geldert, L. P., Sheriff, R. E. and Keys, K. A (1976). Applied geophysics, New York: Cambridge University Press. Page 860.

[17] Todd, D. K. (2004). Groundwater hydrology, 2nd edition, John Wiley \& Sons, New York.

[18] Tyson, A. A. (1993). Georgia's Groundwater resources, U.S. Geological survey bulletin. Page 1096: 1-11.

[19] Zohdy, A. A. R., Eaton, C. P. and Mabey, D. R. (1974). Application of surface geophysics to ground water investigation. Tech. Water resources investigation, Washington, U.S., Geophysics Survey.

[20] www.Crossriverwatch.Com, 2013 